ARTICLE

Received 4 Oct 2012 | Accepted 1 Feb 2013 | Published 5 Mar $2013 \quad$ DOl: 10.1038/ncomms2570

\title{
The origins of the enigmatic Falkland Islands wolf
}

\author{
Jeremy J. Austin ${ }^{1,2, \star}$, Julien Soubrier ${ }^{1, \star}$, Francisco J. Prevosti ${ }^{3}$, Luciano Prates ${ }^{4}$, Valentina Trejo ${ }^{5}$, \\ Francisco Mena ${ }^{6} \&$ Alan Cooper ${ }^{1}$
}

The origins of the extinct Falkland Islands wolf (FIW), Dusicyon australis, have remained a mystery since it was first recorded by Europeans in the seventeenth century. It is the only terrestrial mammal on the Falkland Islands (also known as the Malvinas Islands), which lie $\sim 460 \mathrm{~km}$ from Argentina, leading to suggestions of either human-mediated transport or overwater dispersal. Previous studies used ancient DNA from museum specimens to suggest that the FIW diverged from its closest living relative, the South American maned wolf (Chrysocyon brachyurus) around $7 \mathrm{Ma}$, and colonized the islands $\sim 330$ ka by unknown means. Here we retrieve ancient DNA from subfossils of an extinct mainland relative, Dusicyon avus, and reveal the FIW lineage became isolated only $16 \mathrm{ka}$ (8-31 ka), during the last glacial phase. Submarine terraces, formed on the Argentine coastal shelf by low sea-stands during this period, suggest that the FIW colonized via a narrow, shallow marine strait, potentially while it was frozen over.

\footnotetext{
${ }^{1}$ Australian Centre for Ancient DNA, School of Earth and Environmental Sciences, The University of Adelaide, North Terrace, Adelaide, South Australia 5005 Australia. ${ }^{2}$ Department of Sciences, Museum Victoria, Carlton Gardens, Melbourne, Victoria 3001, Australia. ${ }^{3}$ División of Mastozoología, Museo Argentino de Ciencias Naturales 'Bernardino Rivadavia'-CONICET, Avenida Angel Gallardo 470, Buenos Aires C1405DJR, Argentina. ${ }^{4}$ División of Arqueología, Museo de La Plata, La Plata 1900, Argentina. ${ }^{5}$ Martín Alonso Pinzón 6511, Las Condes, Santiago, Chile. ${ }^{6}$ Centro de Investigación en Ecosistemas de la Patagonia (R10C1003), I. Serrano 509, Coyhaique, Chile. ${ }^{\star}$ These authors contributed equally to this work. Correspondence and requests for materials should be addressed to A.C. (email: alan.cooper@adelaide.edu.au).
} 
D

uring the Pleistocene (ca. 2.6 Ma-12 ka) South America supported a diverse canid fauna including large hypercarnivorous species (that is, Theriodictis spp., Protocyon spp., $\left.{ }^{1-4}\right)$, as well as smaller species such as the Falkland Islands wolf (FIW) and a related fox found on the mainland, Dusicyon avus (Fig. 1). Most of these species became extinct during the Pleistocene, with D. avus extinct by the late Holocene, and the FIW extinct in the nineteenth century following human hunting ${ }^{4-7}$. The origin of the FIW has been a natural history mystery for over 320 years $^{8}$. Following his encounter with the species in 1,834, Darwin commented 'As far as I am aware, there is no other instance in any part of the world, of so small a mass of broken land, distant from a continent, possessing so large a quadruped peculiar to itself ${ }^{9}$. The mystery is deepened by the absence of any other terrestrial mammals on the islands. While the flora and fauna of the islands show overwhelming Patagonian biogeographical affinities ${ }^{10}$, the physical isolation of the islands ( $\sim 460 \mathrm{~km}$ from the South American mainland) has resulted in a number of theories to explain the origin of the FIW. These include semi-domestication and transport of a continental ancestor by humans sometime after their arrival in southern South America $\sim 13-14.5 \mathrm{ka}$ (refs 11,12 ) or natural dispersal via rafting on ice or over a land bridge during Pleistocene glacial sea level minima ${ }^{1,13-15}$. Recently, ancient DNA analysis revealed the FIW to be a unique South American endemic only distantly related to the living South American maned wolf (Chrysocyon brachyurus $)^{7}$. However, uncertainty about the canid phylogenetic tree and ambiguous and/or imprecise fossil calibrations limited

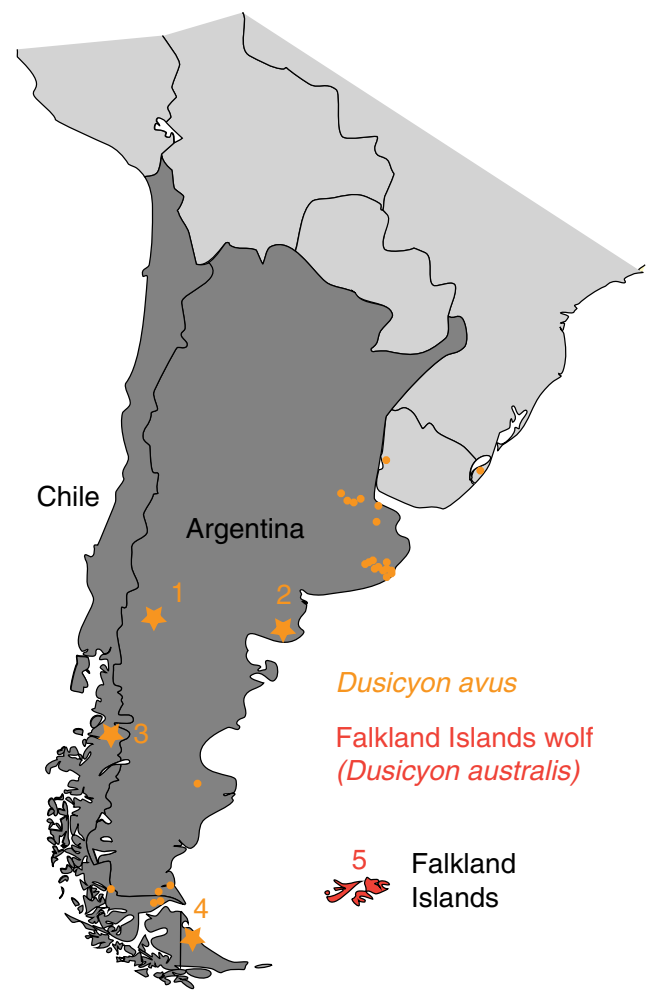

Figure 1 | Specimen distribution. Distribution map of the specimens analysed. The geographical locations of Dusicyon avus specimens known from late Pleistocene to late Holocene sites are shown as orange dots, with the localities of sampled specimens as orange stars. The latter are (1): La Marcelina 1, Rio Negro, Argentina; (2): Loma de los Muertos, Rio Negro, Argentina; (3): Baño Nuevo-1 Cave, Chile; (4): Perro 1 site, Tierra del Fuego, Argentina. Five specimens of Falkland Islands Wolf (FIW) (red) from museum collections were previously analysed, (5): Falkland or Malvinas Islands. the power of the analysis to an approximate divergence date for the FIW and maned wolf of $6.7 \mathrm{Ma}(4.2-8.9 \mathrm{Ma})$. The molecular evolutionary rate estimated in this analysis was also used to calculate the time to the most recent common ancestor (TMRCA) of five museum specimens of the FIW as $330 \mathrm{ka}$ (95\% highest posterior density (HPD) 70-640 ka), and this date was used as a proxy for the colonization age of the Falkland Islands. However, even if this date estimate was approximately accurate, the colonization event could have been considerably older or younger than this depending on the demographic history, any subsequent lineage extinctions ${ }^{16}$, and the relationship between the FIW and unsampled mainland relatives ${ }^{17}$. Furthermore, the use of external fossil calibrations to date recent events is known to be problematic due to the temporal dependency of molecular rates $^{18,19}$. Either way, while the estimated $330 \mathrm{ka}$ date and wide error margins (70-640 ka) clearly predates human arrival, it provided little evidence as to how the FIW might have colonized the islands.

Critically, the genetic analysis of the FIW did not include the putative mainland close relative $D$. avus, whose phylogenetic relationship has not been tested. D. avus had a clear archaeological association and temporal overlap with modern humans until extinction $\sim 3 \mathrm{ka}$ (ref. 6), raising the possibility of human transport to the islands. To investigate this issue and characterize the genetic diversity and phylogenetic relationships of this extinct canid, we extracted and sequenced $1,069 \mathrm{bp}$ of ancient mitochondrial DNA from six specimens of $D$. avus collected across Argentina and Chile, ranging in age from 7,800-3,000 yr BP. We also compared the genetic signals with morphological data from nearly all the extinct and living species of South American canids, a wide sample of other Caninae, and fossils of the extinct subfamilies Hesperocyonidae and Borophaginae ${ }^{3}$.

\section{Results}

Sequences. A combined $1,069 \mathrm{bp}$ of mtDNA COII and cytochrome $b$ sequence was obtained from six out of seven $D$. avus specimens (Supplementary Table S1). No samples produced PCR products for the four nuclear gene targets. All PCR and sequencing results were replicated at least once and produced identical results, suggesting a minimal contribution from damage-related artefacts.

Topology. Both ML and Bayesian molecular analyses confirm that $D$. avus is the closest relative of the FIW with strong statistical support (Fig. 2), and only six fixed transition differences separate the FIW and D. avus (Supplementary Fig. S1, uncorrected sequence divergence $=0.56 \%$ ). Ten additional variable sites defined three haplotypes within the FIW (from five individuals) and four haplotypes in $D$. avus (from six individuals) (Supplementary Fig. S1). Strong support is also recovered for the monophyly of the Dusicyon clade, its sister taxon relationship to the maned wolf, with the bush dog as the outgroup. While $D$. avus was weakly recovered as paraphyletic in the topological analysis, D. avus and the FIW were strongly supported as reciprocally monophyletic in analyses using a molecular clock and either external or internal calibrations (Fig. 3 and Supplementary Fig. S2). The combined morphological and molecular analysis recovered one most parsimonious tree of 3782.017 steps (Supplementary Figs S3 and S4), similar to the one previously reported by Prevosti ${ }^{3}$, but $D$. avus and FIW are a monophyletic group sister of C. brachyurus (Supplementary Figs S2, S3 and S4).

Dating. Date randomization tests confirmed that sufficient signal existed in the dated concatenated sequences from the six $D$. avus individuals to provide appropriate internal temporal calibration 


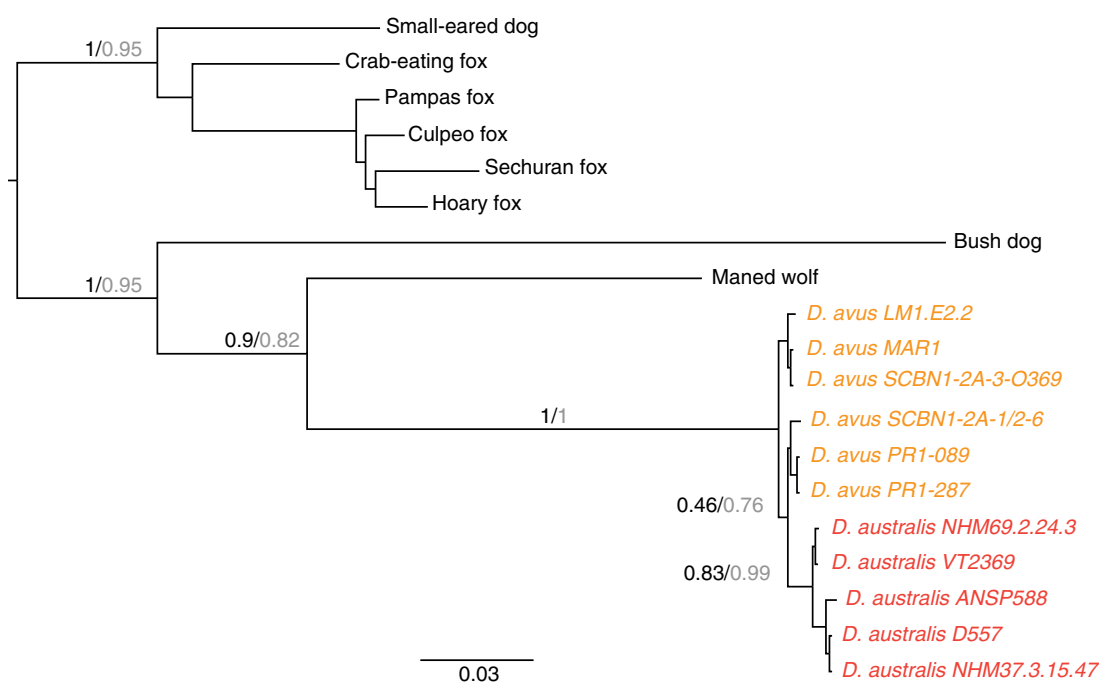

Figure 2 | Phylogenetic position of D. avus and FIW. Phylogenetic tree showing the topological placement of D. avus, FIW and South American canids, based on the analysis of 1,069bp of mitochondrial cyt $b$ and COll genes. The same topology was recovered using Bayesian (MrBayes, black support values) and maximum likelihood analyses (PhyML, grey support values). The FIW forms a monophyletic group separate from the mainland $D$. avus, which is weakly supported as being paraphyletic, with the maned wolf as the closest living relative to the extinct Dusicyon clade.

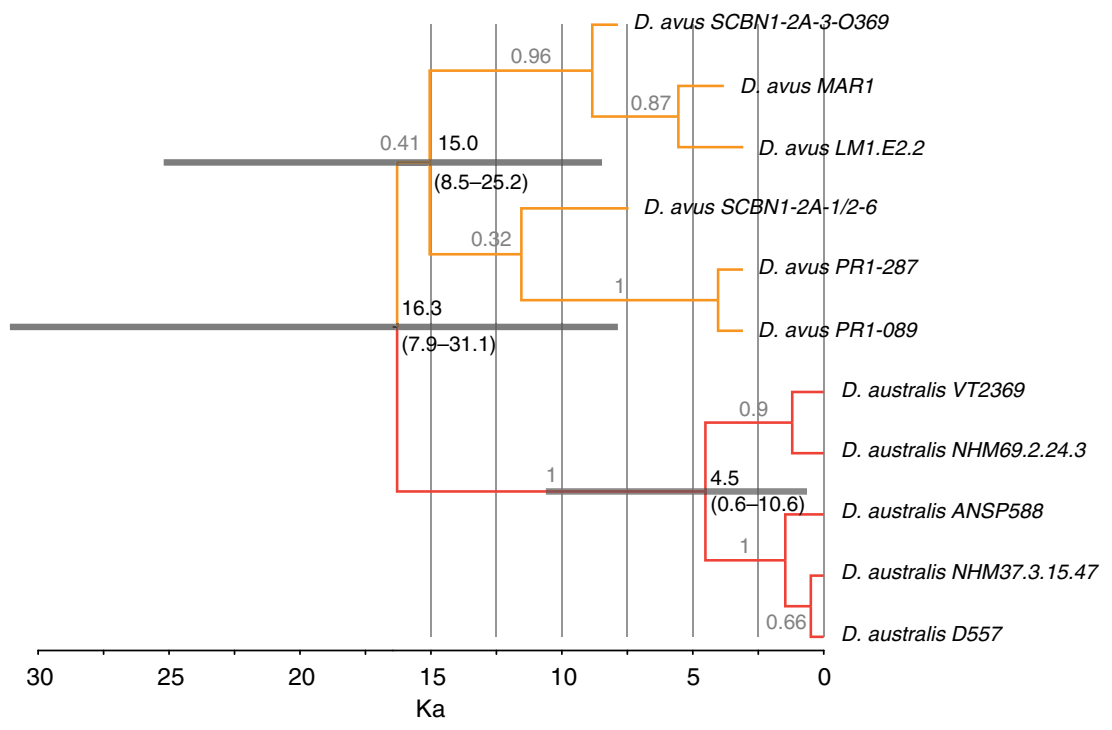

Figure 3 | Dated phylogeny of $\boldsymbol{D}$. avus and FIW (D. australis). Unconstrained phylogeny of $D$. avus and FIW using a molecular clock, with the radiocarbondated ancient samples as temporally proximate calibration points. The timescale is given in thousand years (ka). The two Dusicyon species are strongly supported as reciprocally monophyletic clades in this analysis, and when external canid fossil calibration points are used (Supplementary Fig S2). The two species are estimated to have diverged during the last glacial phase (7.9-31.1 ka), with the upper bound overlapping with the first human presence in Patagonia ${ }^{11,12}$. The topology is a maximum clade credibility tree from BEAST with 95\% HPD of the calculated node ages represented as grey bars. The use of ancient samples to provide tip-date calibrations led to considerably younger TMRCA estimates for the Dusicyon clades than previous estimates ( 330 ka for $\mathrm{FIW}^{7}$ ), which relied on deep canid fossil calibrations of imprecise phylogenetic and temporal position.

information at the tip of the tree to facilitate molecular dating ${ }^{19}$ (Supplementary Fig. S5). Bayesian analyses estimate that the FIW diverged from D. avus recently, around $16.3 \mathrm{ka}$ (95\% HPD 7.9$31.1 \mathrm{ka})$. The TMRCA for the D. avus, and for the FIW, specimens were estimated at $15.0 \mathrm{ka}$ (95\% HPD 8.5-25.2 ka) and $4.5 \mathrm{ka}$ (95\% HPD 0.6-10.6 ka), respectively (Fig. 3). In contrast, analyses using several deep, and poorly constrained canid fossil calibration points originally used in Slater et al. ${ }^{7}$ produced much older age estimates, close to those previously reported (Supplementary Figs S2, Supplementary Table S2 and Supplementary Methods).
Interestingly, while the low intra-specific mtDNA diversity within the FIW $(\pi=0.0021)$ was consistent with that of other insular species, the diversity within $D$. avus was similar $(\pi=0.0026)$, despite the much larger geographic and ecological range of the samples. Furthermore, no phylogeographic patterns were evident within the D. avus sequences (Supplementary Fig. S1) despite the wide sampling area.

\section{Discussion}

The estimated latest Pleistocene date of $16 \mathrm{ka}(8-31 \mathrm{ka})$ for the origin of the FIW is consistent with events associated with the 
Last Glacial Maximum (LGM) ca. 26-19 ka (ref. 20), and is considerably younger than the previously estimated date of $330 \mathrm{ka}$ (ref. 7). The accuracy of molecular divergence date estimates is directly related to the quality of calibration data, and their proximity to the date of interest. In this regard, the use of deep fossil calibration points has been shown to be inappropriate for intra-specific and recent inter-specific divergences ${ }^{18,19}$, such as those within Dusicyon. The radiocarbon dates associated with the ancient sequences of $D$. avus provide much closer calibration points to the late Pleistocene events under consideration than the early canid fossils used in Slater et al. ${ }^{7}$, and importantly do not suffer from the same uncertainty over taxonomic identification and phylogenetic position. Although additional internal calibration points would no doubt help refine the inferred dates, the randomization analyses confirm that the heterochronous Holocene D. avus sequences contain sufficient temporal information to calibrate the recent evolutionary history of Dusicyon (Supplementary Fig. S5 and Supplementary Methods).

The data do not support a recent origin for the FIW via human transport from a source population of $D$. avus on the South
American mainland due to the estimated $16 \mathrm{ka}$ divergence date and the reciprocal monophyly of the two species in calibrated analyses. Although the confidence interval $(8-31 \mathrm{ka})$ for the divergence event overlaps with the earliest human presence in Patagonia (13-14.5 ka, (refs 11,12), and human agency cannot therefore be ruled out, the genetic isolation of the FIW (presumably via transfer to the Falkland Islands) would have had to occur only once during the earliest phases of human occupation in Patagonia (that is, $>8 \mathrm{ka}$ ), which seems improbable. Furthermore, the estimated 16 ka divergence date is unlikely to be an overestimate due to the existence of undetected and phylogenetically closer source populations of $D$. avus, because the geographically widespread $D$. avus samples have low nucleotide diversity and lack phylogeographic structure. Indeed, the young TMRCA of $\sim 15 \mathrm{ka}$ for $D$. avus and the lack of geographic structure and low genetic diversity suggest that the range of this species has recently expanded across the Patagonian and Pampean regions, potentially from a LGM refugium.

A pre-human dispersal of the FIW requires either a land bridge during low sea level stands or a marine crossing, but the absence of other terrestrial mammals on the Falkland Islands strongly

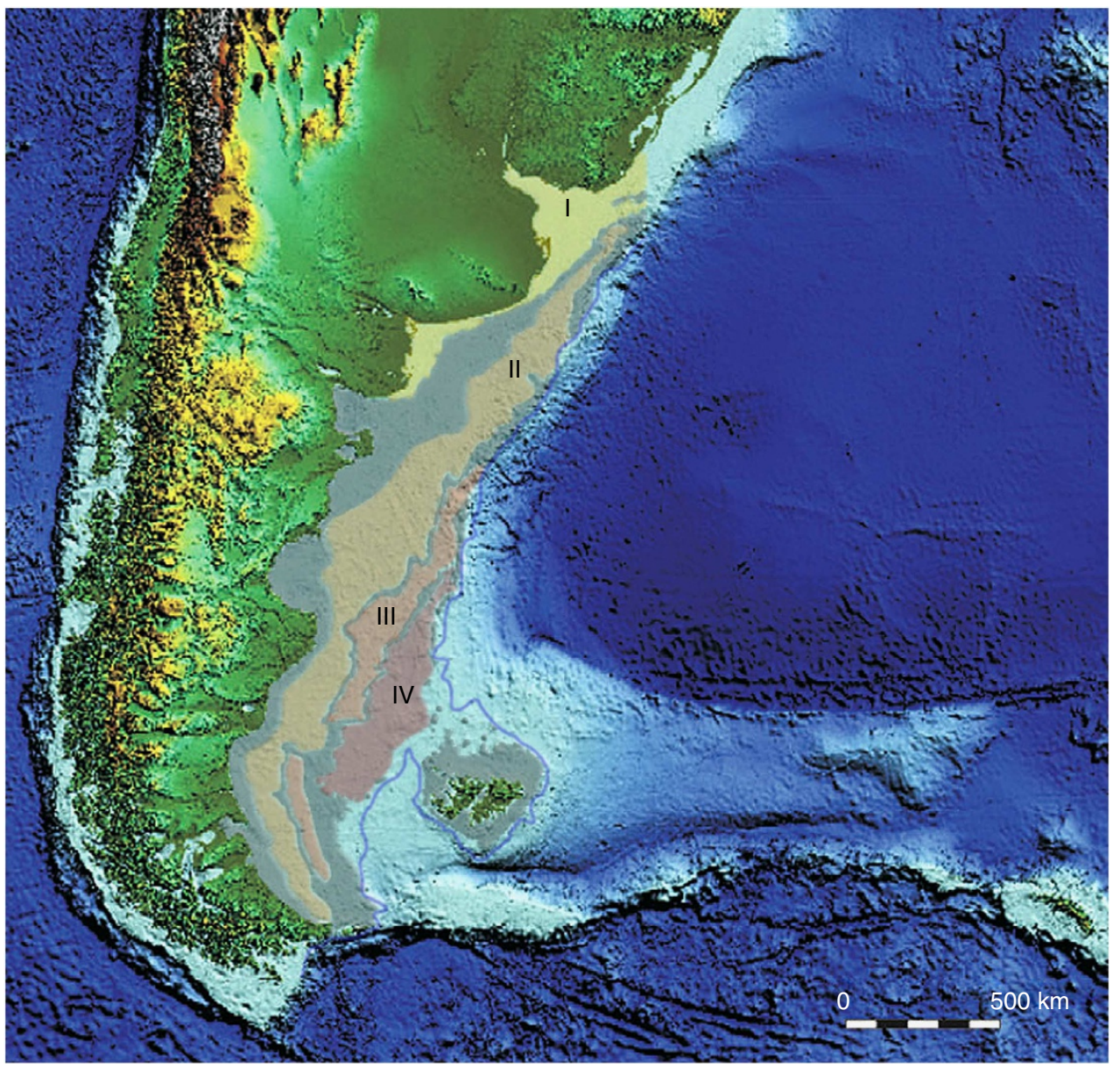

Figure 4 | Submarine terraces between the mainland and the Falkland Islands. The four submarine terraces (levels I-IV) along the continental shelf (light blue) between the South American continent and the Falkland Islands: level I= $-25 /-30 \mathrm{~m}$ isobath; level II = $-85 /-95 \mathrm{~m}$; level III = $-110 /-120 \mathrm{~m}$ and level IV $=-130 /-150 \mathrm{~m}$ (ref. 21). Terrace I has been dated ca. $11 \mathrm{ka}$, and Terrace II ca. $15 \mathrm{ka}$ (ref. 21), with the latter being consistent with the global Meltwater Pulse 1A, associated with the West Antarctic Ice Sheet ${ }^{20}$. Terraces III and IV are undated but are thought to reflect earlier phases of the LGM, with the depth differential matching the rapid $10 \mathrm{~m}$ rise from the LGM lowstand caused by the global Meltwater Pulse at 19-20 ka (ref. 20). The projected sea level position at $-140 \mathrm{~m}$ is drawn in grey, representing the peak low sea-stand during the LGM (data from Ponce et al. ${ }^{21}$ ). At this point the Falkland Islands would have been separated from the mainland by a shallow marine strait estimated to be as little as $20 \mathrm{~km}$ wide and only $10-30 \mathrm{~m}$ deep. It is suggested that this is likely to periodically have been covered by ice, or facilitated ice rafting, during peak glacial conditions. 
argues against a continuous land bridge connection to the mainland. The particularly shallow slope of the Argentine continental shelf means that lowered sea levels dramatically reduce the size of the marine strait separating the Falkland Islands, which currently has a minimum depth of ca. $160 \mathrm{~m}$ (ref. 21). During the height of the LGM (26-19ka) global sea levels were around $130 \mathrm{~m}$ lower, which exposed an enormous coastal plain off the Argentine coast, while the Falkland islands landmass was about four times larger than the present ${ }^{21-23}$. Four pronounced submarine terraces detected on the coastal shelf (Fig. 4) are thought to record low sea-stands at various points during the $\mathrm{LGM}^{24}$. The two shallowest have been dated ca. $11 \mathrm{ka}$ $(-35 /-40 \mathrm{~m}$ isobath) and $15 \mathrm{ka}(-80 /-90 \mathrm{~m})$ (ref. 21), with the timing of the latter being consistent with Meltwater Pulse 1A, associated with the onset of the retreat of the West Antarctic Ice Shelf ${ }^{20}$. Two deeper terraces situated at the $-110 /-120 \mathrm{~m}$ and the $-130 / 150 \mathrm{~m}$ isobaths remain undated, but are thought to represent low sea-stands during earlier phases of the LGM. The deepest terrace $(-130 / 150 \mathrm{~m})$ is presumably the oldest and corresponds to the lowest isostatic conditions, as it has not been degraded through subsequent near-shore activity. The depth of the terrace matches the estimated minimal sea level during the LGM (ca. $-130 \mathrm{~m}$ ), but could also relate to earlier glacial events $^{24}$. However, the difference between the $-110 / 120 \mathrm{~m}$ and $-130 / 150 \mathrm{~m}$ terraces is consistent with a rapid $10 \mathrm{~m}$ rise from LGM lowstand sea levels associated with the 19-20 ka Meltwater Pulse caused by the widespread retreat of northern hemisphere ice sheets ${ }^{20}$. Either way, the molecular date estimate for the divergence of the FIW of $16 \mathrm{ka}$ (range 8-31 ka) is consistent with colonization during the LGM, when the submarine terraces indicate the marine strait was both narrow and shallow.

A low sea-stand between the -130 and $-150 \mathrm{~m}$ isobaths would drastically reduce the size of the marine strait separating the Falkland Islands, potentially to just $20-30 \mathrm{~km}$ (Fig. 4), with an estimated minimum depth of $10-30 \mathrm{~m}$. It is possible that the ancestors of the FIW were transported across this strait by ice rafting during this period, as has been suggested, but it seems more likely that such a shallow marine strait would be periodically frozen over by continuous sea ice and/or glacial outflow to produce an ephemeral connection that could act as a filter, rather than a corridor. Individuals or packs of the ancestor of FIW pursuing marine food sources (for example, seals, penguins, seabirds) on the margins of the ice would have an increased likelihood of colonization compared with other South American endemic mammals that would not cross large ice-fields due to either habitat or behaviour. An interesting question is why previous glacial maxima did not lead to other mammal colonizations of the Falkland Islands, as the marine strait is thought to have been shallower during earlier phases of the Pleistocene before the erosion of soft sediments ${ }^{21}$. It is possible that if there were such previous residents they may have gone extinct without leaving a fossil record.

The greatly improved resolution provided by genetic data from the closest mainland relative allows us to conclude that the ancestor of the FIW likely colonized the Falkland Islands via mobile or static ice, crossing a narrow strait during the Last Glacial Maximum in Patagonia.

\section{Methods}

Samples. Seven D. avus teeth representing different individuals (Supplementary Table S3) were obtained from four sites in Patagonia: La Marcelina, Rio Negro (one tooth); Loma de los Muertos, Rio Negro (one tooth) and Perro 1 site; Tierra del Fuego (two teeth) in Argentina; and Baño Nuevo-1 Cave (three teeth) in Chile. One premolar from Baño Nuevo-1 cave has been dated to 7,860 $\pm 78 \mathrm{cal}$. yr BP (UCIAMS-19490, Supplementary Table S3), while specimens from Perro 1, Loma de los Muertos and La Marcelina 1 were dated to 3,085 $\pm 133,3,072 \pm 151$, and $3,814 \pm 117$ cal. yr BP (AA75297, AA83516, AA90951; (refs 6,23) Supplementary
Table S3), respectively. A second specimen from Baño Nuevo-1 cave was undated but assigned a prior mean age of 7,500 cal. yr BP (6,000-9,000 cal. yr BP 95\% range, Supplementary Table S3) based on an archaeological association with dated remains from the same site. Teeth were obtained from recently described specimens that have diagnostic morphological features of $D$. avus for example, large lower carnassial, a lower fourth premolar with a second distal accessory cusp and a narrow distal cingulum ${ }^{4,6}$. The FIW exhibits differences in dental morphology from $D$. avus including a more reduced protocone in the $\mathrm{P} 4$, smaller metaconid in the $\mathrm{m} 1$, and taller and more acute principal cusps of the premolars ${ }^{6}$. These characters are generally associated with a more carnivorous diet ${ }^{25,26}$ and potentially reflect the limited dietary breadth of the FIW ${ }^{27,28}$

Molecular analyses. To avoid the potential for contamination of D. avus samples with contemporary canid DNA or previously amplified FIW PCR products ${ }^{7}$, all pre-PCR work was performed in a dedicated ancient DNA laboratory geographically separated (by $\sim 1.5 \mathrm{~km}$ ) from post-PCR and other molecular biology laboratories at the Australian Centre for Ancient DNA, University of Adelaide, South Australia. No contemporary canid DNA had ever been present in the pre-PCR laboratory. The ancient DNA facility includes high-efficiency particulate air-filtered positive air pressure with one-way air flow, overhead ultraviolet (UV) lights, individual work-rooms, the use of dead-air glove boxes with internal UV lights for DNA extractions and PCR set-up, regular decontamination of all work areas and equipment with sodium hypochlorite, personal protective equipment including full body suit, face mask, face shield, boots and triple-gloving and strict one-way movement of personnel (shower $>$ freshly laundered clothes $>$ ancient DNA laboratory $>$ post-PCR laboratory).

A negative extraction control was included with every set of DNA extractions and all extractions were carried out in small sets and generally included samples from phylogenetically divergent non-canid species. DNA was extracted using a modified silica-based method ${ }^{29}$ designed to maximize recovery of PCR-amplifiable DNA from ancient bone and tooth specimens while minimizing coextraction of PCR inhibitors.

Short fragments of mitochondrial (166-240 bp) and nuclear (108-173 bp) DNA were targeted by PCR, to assemble a 652-bp fragment of the mtDNA COII gene, a 394-bp fragment of the mtDNA cytochrome $b$ gene, and four nuclear loci $(\mathrm{CH} 21$ VANGL, VTN(SNP), VTN(indel) ${ }^{7}$, (Supplementary Table S4). One microlitre of extract, in parallel with extraction controls and negative PCR controls, was amplified in a $25-\mu \mathrm{l}$ PCR containing: $1 \times$ Platinum Taq High Fidelity Buffer (Invitrogen), $2 \mathrm{mM} \mathrm{MgSO}_{4}, 0.4 \mathrm{mM}$ each primer, $0.25 \mathrm{mM}$ each dNTP, $0.5 \mathrm{U}$ Platinum Taq DNA Polymerase High Fidelity, $1 \mathrm{mg} \mathrm{ml}^{-1}$ RSA (Sigma-Aldrich) and sterile $\mathrm{H}_{2}$. PCRs were run on a Palmcycler (Corbett Research) under the following conditions: initial denaturation at $94^{\circ} \mathrm{C}$ for $1 \mathrm{~min}$; 50 cycles of denaturation at $94^{\circ} \mathrm{C}$ for $15 \mathrm{~s}$; primer annealing at $55^{\circ} \mathrm{C}$ for $15 \mathrm{~s}$; elongation at $68^{\circ} \mathrm{C}$ for $30 \mathrm{~s}$; a final elongation step at $68^{\circ} \mathrm{C}$ for $10 \mathrm{~min}$. PCR products were visualized under UV light on a $3.5 \%$ agarose gel stained with ethidium bromide. Successful amplifications were purified using Ampure (Agencourt) according to the manufacturer's instructions and sequenced directly using Big Dye chemistry and an ABI 3130XL Genetic Analyzer (Applied Biosystems). All positive PCR and sequencing results were repeated to ensure reproducibility.

Sequence alignment. COII and cytochrome $b$ sequences were generated from six D. avus specimens and aligned with the available sequences from five FIW specimens, and the eight South American canids used by Slater et al. ${ }^{7}$ (maned wolfChrysocyon brachyurus, bush dog-Speothos venaticus, crab-eating fox-Cerdocyon thous, small-eared dog-Atelocynus microtis, sechuran fox-Lycalopex sechurae, culpeo fox-Lycalopex culpaeus, pampas fox-Lycalopex gymnocercus, hoary foxLycalopex vetulus). The South American canids have previously been shown to be monophyletic ${ }^{7}$

Phylogenetic analyses. To study the phylogenetic placement of $D$. avus, we performed both Bayesian (MrBayes ${ }^{30}$ ) and maximum likelihood ( $\mathrm{PhyML}^{31}$ ) analyses on the entire data set (D. avus, FIW and eight South American canids, as described above). The best substitution model was selected through comparison of Bayesian information criteria scores using ModelGenerator v0.85 (ref. 32).

In addition, a haplotype network showing genealogical relationships between all D. avus and FIW sequences was generated using statistical parsimony implemented in TCS v1.17 (ref. 33). Nucleotide diversity within D. avus and FIW was calculated using DnaSP v5.10.01 (ref. 34).

We also performed a total evidence analysis combining the new mitochondrial sequences with previously reported morphological, behavioural and genetic data for South American canids ${ }^{35}$. The individual mitochondrial sequences of $D$. avus and FIW were each combined into a single consensus sequence using the programme Bioedit 7.0.5.3 (ref. 36), and the variable sites were scored as polymorphic using the IUPAC code. The mitochondrial sequences were added to a previously published 'total evidence' matrix ${ }^{3}$ containing dental and skeletal characters, behavioural and life history traits ${ }^{37}$, and 22 nuclear and 3 mitochondrial genes from a wide sampling of living canids and several fossil representatives (for whom only dental and skeletal data was available). Sequence gaps were coded as a fifth state. The combined matrix was analysed under Maximum parsimony with 
the software TNT version 1.1 (ref. 38) under equal weighting (SI). Trees were obtained from heuristic searches with 1,000 random-addition sequence replicates and tree bisection-reconnection (TBR) branch swapping, supplemented by a TBR round on the resulting shortest-length trees. Additional searches were conducted using the sectorial-searches, tree-drifting and tree-fusing algorithms ${ }^{39}$, but they found the same trees. Branch support was quantified with symmetrical-resampling jackknifing frequencies and frequency differences (5,000 resamples; ref. 40). The trees were rooted with the basal canid Hesperocyon gregarius. Branches were collapsed following the rule number 1 , where any branch with at least one reconstruction with 0 changes is collapsed (minimal branch length $=0$; see ref. 41).

Calibration using fossils versus internal radiocarbon dates. To examine the problems caused by the temporal dependency of molecular dates, we performed molecular dating analyses using either internal (radiocarbon), or external (fossil), dates. The advantages of using internal calibrations to study recent evolutionary events are well established ${ }^{18,19}$, and given a divergence event thought to be late Pleistocene (natural dispersal) or Holocene (human dispersal), the internal radiocarbon dates for $D$. avus appear far more appropriate than external fossil dates of 4-32 Ma (with largely unknown error margins) and uncertain taxonomic/ phylogenetic position.

Radiocarbon ages were converted to calibrated ages using the CALIB 6.0.1 software available at http://intcal.qub.ac.uk/calib/ ${ }^{42,43}$, using the Southern Hemisphere SHCal04 curve ${ }^{44}$ and two sigma ranges. A Bayesian phylogenetic analysis was performed using the FIW and $D$. avus sequences to estimate the TMRCA of each species, and their immediate ancestor, using the D. avus radiocarbon dates as the sole calibration points. The best substitution model was selected through comparison of Bayesian information criteria scores using ModelGenerator v0.85 (ref. 32). Phylogenetic analyses were performed with BEAST 1.6.2 (ref. 45) using a strict molecular clock (analyses using an uncorrelated lognormal relaxed clock could not reject the strict clock assumption), and the Bayesian skyride demographic model ${ }^{46}$ to account for demographic changes through time. The results were processed with Tracer v1.5 (ref. 47) to check that each sampled parameter had an effective sample size over 200.

To test whether the signal from the radiocarbon dates associated with the ancient sequences is sufficient to calibrate the Dusicyon phylogeny, a 'date randomization test' $^{48}$ was conducted. This test consists of randomizing all dates associated with the sequences (including modern ones), and then replicating the phylogenetic analysis. Ten replicates of the BEAST phylogeny described in the main text were performed using different iterations of randomized dates.

To examine the impact of using external canid fossils as calibration points, we repeated the initial molecular analysis of the FIW by Slater et al. ${ }^{7}$, but with the addition of six new sequences from $D$. avus (Supplementary Fig. S2).

\section{References}

1. Berta, A. Origin, diversification, and zoogeography of the South American Canidae. Fieldiana: Zoology 39, 455-471 (1987).

2. Kraglievich, L. Contribution to the knowledge of the extinct canids of South America. Anales de la Sociedad Cientifica Argentina 106, 25-66 (1928).

3. Prevosti, F. J. Phylogeny of the large extinct South American Canids (Mammalia, Carnivora, Canidae) using a 'total evidence' approach. Cladistics 26, 456-481 (2010).

4. Prevosti, F. J., Ubilla, M. \& Perea, D. Large extinct canids from the Pleistocene of Uruguay: systematic, biogeographic and palaeoecological remarks. Historical Biol. 21, 79-89 (2009).

5. Cione, A. L., Tonni, E. P. \& Soibelzon, L. H. In American Megafaunal Extinctions at the End of the Pleistocene. (ed. Haynes, G.) 125-144 (Springer, 2009).

6. Prevosti, F. J., Santiago, F., Prates, L. \& Salemme, M. Constraining the time of extinction of the South American fox Dusicyon avus (Carnivora, Canidae) during the late Holocene. Quatern. Int. 245, 209-217 (2011).

7. Slater, G. J. et al. Evolutionary history of the Falklands wolf. Curr. Biol. 19, R937-R938 (2009).

8. Simson, R. in Sloane MS 86 (672) (British Library, London, 1689).

9. Darwin, C. Narrative of the surveying voyages of His Majesty's Ships Adventure and Beagle between the years 1826 and 1836, describing their examination of the southern shores of South America, and the Beagle's circumnavigation of the globe. Vol. III (1839).

10. McDowall, R. M. Falkland Islands biogeography: converging trajectories in the South Atlantic Ocean. J. Biogeography 32, 49-62 (2005).

11. Dillehay, T. D. \& Collins, M. B. Early cultural evidence from Monte-Verde in Chile. Nature 332, 150-152 (1988).

12. Steele, J. \& Politis, G. AMS C-14 dating of early human occupation of southern South America. J. Archaeol. Sci. 36, 419-429 (2009).

13. Clutton-Brock, J., Corbet, G. G. \& Hills, M. A review of the family Canidae, with a classification by numerical methods. Bull. Br. Mus. (Nat. His.) Zool. 29, 119-199 (1976).

14. FitzRoy, R. Narrative of the surveying voyages of His Majesty's Ships Adventure and Beagle between the years 1826 and 1836, describing their examination of the southern shores of South America, and the Beagle's circumnavigation of the globe. Proceedings of the second expedition (under the command of Captain Robert FitzRoy R. N.) 1831-1836 (Henry Colburn, 1839).

15. Wang, X., Tedford, R. H. \& Anton, M. Dogs: their Fossil Relatives and Evolutionary History (Columbia Univ. Press, 2008).

16. Poux, C. et al. Asynchronous colonization of Madagascar by the four endemic clades of primates, tenrecs, carnivores, and rodents as inferred from nuclear genes. Syst. Biol. 54, 719-730 (2005).

17. Emerson, B. Evolution on oceanic islands: molecular phylogenetic approaches to understanding pattern and process. Mol. Ecol. 11, 951-966 (2002).

18. Ho, S. Y. W. et al. Time-dependent rates of molecular evolution. Mol. Ecol. 20, 3087-3101 (2011).

19. Ho, S. Y. W., Saarma, U., Barnett, R., Haile, J. \& Shapiro, B. The effect of inappropriate calibration: three case studies in molecular ecology. Plos One 3, e1615 (2008).

20. Clark, P. U. et al. The last glacial maximum. Science 325, 710-714 (2009).

21. Ponce, J. F., Rabassa, J., Coronato, A. \& Borromei, A. M. Palaeogeographical evolution of the Atlantic coast of Pampa and Patagonia from the last glacial maximum to the Middle Holocene. Biol. J. Linnean Soc. 103, 363-379 (2011).

22. Rabassa, J. Late Cenozoic of Patagonia and Tierra del Fuego. 151-204 (Elsevier, 2008).

23. Rostami, K., Peltier, W. R. \& Mangini, A. Quaternary marine terraces, sea-level changes and uplift history of Patagonia, Argentina: comparisons with predictions of the ICE-4G (VM2) model of the global process of glacial isostatic adjustment. Quat. Sci. Rev. 19, 1495-1525 (2000).

24. Parker, G., Violante, R. A. \& Paterlini, C. M. Report of the XIII Argentine Geological Congress and the III Hydrocarbon Exploration Congress 1-16 (Associación Geológica Argentina-Instituto Argentino del Petróleo, 1996).

25. Berta, A. Quaternary Evolution and Biogeography of the Large South American Canidae (Mammalia: Carnivora) (University of California Publications in Geological Sciences, 1989).

26. Van Valkenburgh, B. Iterative evolution of hypercarnivory in canids (Mammalia: Carnivora): evolutionary interactions among sympatric predators. Paleobiology 17, 340-362 (1991).

27. Mivart, G. Dogs, Jackals, Wolves, and Foxes: a Monograph of the Canidae (Taylor and Francis, 1890).

28. Waterhouse, G. R. Mammalia Part 2 of the Zoology of the Voyage of HMS Beagle. Edited and superintended by Charles Darwin (Smith Elder and Co., 1939).

29. Rohland, N. \& Hofreiter, M. Ancient DNA extraction from bones and teeth. Nat. Protocols 2, 1756-1762 (2007).

30. Ronquist, F. \& Huelsenbeck, J. P. MrBayes 3: Bayesian phylogenetic inference under mixed models. Bioinformatics 19, 1572-1574 (2003).

31. Guindon, S. \& Gascuel, O. A simple, fast, and accurate algorithm to estimate large phylogenies by maximum likelihood. Syst. Biol. 52, 696-704 (2003).

32. Keane, T. M., Creevey, C. J., Pentony, M. M., Naughton, T. J. \& McLnerney, J. O. Assessment of methods for amino acid matrix selection and their use on empirical data shows that ad hoc assumptions for choice of matrix are not justified. BMC Evol. Biol. 6, 29 (2006).

33. Clement, M., Posada, D. \& Crandall, K. A. TCS: a computer program to estimate gene genealogies. Mol. Ecol. 9, 1657-1659 (2000).

34. Librado, P. \& Rozas, J. DnaSP v5: a software for comprehensive analysis of DNA polymorphism data. Bioinformatics 25, 1451-1452 (2009).

35. Wiens, J. J. Phylogenetic Analysis of Morphological Data 115-145 (Smithsonian, 2000).

36. Hall, T. A. BioEdit: a user-friendly biological sequence alignment editor and analysis program for Windows 95/98/NT. Nucleic Acids Symp. Ser. 41, 95-98 (1999).

37. Zrzavý, J. \& ŘIčánková, V. Phylogeny of Recent Canidae (Mammalia, Carnivora): relative reliability and utility of morphological and molecular datasets. Zoologica Scripta 33, 311-333 (2004).

38. Goloboff, P. A., Farris, J. S. \& Nixon, K. C. TNT, a free program for phylogenetic analysis. Cladistics 24, 774-786 (2008).

39. Goloboff, P. A. Analyzing large data sets in reasonable times: Solutions for composite optima. Cladistics 15, 415-428 (1999).

40. Goloboff, P. A. et al. Improvements to resampling measures of group support. Cladistics 19, 324-332 (2003).

41. Coddington, J. \& Scharff, N. Problems with zero-length branches. Cladistics 10, 415-423 (1994).

42. Reimer, P. J. et al. IntCal09 and Marine09 radiocarbon age calibration curves, 0-50,000 years CAL BP. Radiocarbon 51, 1111-1150 (2009).

43. Stuiver, R. Extended 14C data base and revised CALIB 3.0 14C age calibration program. Radiocarbon 35, 215-230 (1993).

44. McCormac, F. G. et al. SHCal04 Southern Hemisphere calibration, 0-11.0 cal kyr BP. Radiocarbon 46, 1087-1092 (2004).

45. Drummond, A. J. \& Rambaut, A. BEAST: Bayesian evolutionary analysis by sampling trees. BMC Evol. Biol. 7, 214 (2007). 
46. Minin, V. N., Bloomquist, E. W. \& Suchard, M. A. Smooth skyride through a rough skyline: Bayesian coalescent-based inference of population dynamics. Mol. Biol. Evol. 25, 1459-1471 (2008).

47. Rambaut, A. \& Drummond, A. J. Tracer v1.4, Available from beast.bio.ed.ac.uk/ Tracer (2007).

48. Ho, S. Y. W. et al. Bayesian estimation of substitution rates from ancient DNA sequences with low information content. Syst. Biol. 60, 366-375 (2011).

\section{Acknowledgements}

We thank J. Rabassa and J. F. Ponce for comments and access to high-resolution versions of published figures, and F. Martin, M. Salemme, F. Santiago, O. Palacios and M. Silveira for access to the D. avus samples, and the Otago Museum for a sample of their FIW specimen. This work was funded by the Australian Research Council, PICT 2011-309 (ANPCyT), PIP 1054 and PIP 201101-00164 (CONICET).

\section{Author contributions}

A.C. and J.J.A. conceived the study; F.J.P., L.P., V.T. and F.M. provided samples; J.J.A. J.S. and F.J.P. performed the experiments; and A.C., J.S. and J.J.A. wrote the manuscript with input from all authors.

\section{Additional information}

Supplementary Information accompanies this paper at http://www.nature.com/ naturecommunications

Competing financial interests: The authors declare no competing financial interests.

Reprints and permission information is available online at http://npg.nature.com/ reprintsandpermissions/

How to cite this article: Austin, J.J. et al. The origins of the enigmatic Falkland Islands wolf. Nat. Commun. 4:1552 doi: 10.1038/ncomms2570 (2013). 